\title{
SOCIETY ISLANDS (CENTRAL EASTERN POLYNESIA) CHRONOLOGY: 11 RADIOCARBON DATES FOR THE LATE PREHISTORIC EXPANSION AND PROTO- HISTORIC PERIODS IN THE ‘OPUNOHU VALLEY, MO`OREA
}

\author{
Jennifer G Kahn \\ School of Social Science, University of Queensland, Brisbane, Queensland 4072, Australia. Email: j.kahn@uq.edu.au.
}

\begin{abstract}
The chronology of residential site construction and occupation in the upper reaches of the 'Opunohu Valley, Mo'orea, Central Eastern Polynesia, has been debated over the last $15 \mathrm{yr}$. This paper reports a suite of 11 radiocarbon age determinations from excavations at 5 house sites and a simple temple structure (marae). Direct accelerator mass spectrometry (AMS) dating of wood charcoal identified to short-lived taxa confirms site construction and occupation during the mid-15th to 17 th centuries, supporting that maximal population density was in the centuries immediately prior to European contact. The study demonstrates that targeted dating of multiple structures within residential complexes allows for multiple phases of site construction and use to be discriminated. These data are critical for adequately assessing site contemporaneity and the development, maintenance, and expansion of residential groups and their house clusters through time.
\end{abstract}

\section{INTRODUCTION}

The 'Opunohu Valley is the largest windward valley on Mo'orea, which is the second largest of the windward isles of the Society Archipelago (Central Eastern Polynesia). While the 'Opunohu remains perhaps the best studied windward context in the Society Islands, the archipelago has lacked intensive archaeological investigation (Kirch 2000), particularly when compared to other well-studied regions such as Hawai 'i, New Zealand, and even the Marquesas Islands. Over the last $40 \mathrm{yr}$, archaeological survey and excavation in the 'Opunohu Valley have contributed important data concerning the sequence of valley occupation and use, yet the corpus of available radiometric dates numbers only 31 . The current study discusses 11 new accelerator mass spectrometry (AMS) dates from late prehistoric and proto-historic house sites and a simple marae (ceremonial temple site) recently excavated in the upper Tupauruuru sector of the valley (Kahn 2003, 2005; Kahn and Kirch 2003 , 2004). These dates add to the corpus of materials refining the late prehistoric cultural sequence, particularly in the upper Tupauruuru sector, where the sequence of site construction, use, and possible reuse has been a topic of ongoing debate (Descantes 1990, 1993; Green 1996; Green et al. 1967; Lepofsky 1994).

Green's pioneering settlement pattern survey and excavations in the 'Opunohu in the 1960s (Green et al. 1967) provided 6 dates from ceremonial temples (marae) and habitation contexts; these dates were made on bulk charcoal samples using conventional radiocarbon dating techniques available at the time. Some of these dates derived from the Gakushin (GaK) laboratory, and Davidson (1967: 139) argued that at least one of the "Opunohu Valley GaK dates was "contaminated" because the sample yielded a modern date. Later analysis of GaK dates produced in the early 1960s for other Eastern Polynesian sites (Kirch 1984:73, 1986:23; Rolett 1998:53) demonstrated that the lab produced unacceptably recent dates, likely because of significant pretreatment errors or errors in laboratory method, leading many to discount these dates or to use them with caution (Anderson et al. 1994; Lepofsky 1994, 1995; Spriggs and Anderson 1993).

Lepofsky provided additional modern-day reliable ${ }^{14} \mathrm{C}$ measurements for 'Opunohu, including 23 ${ }^{14} \mathrm{C}$ measurements from excavations at agricultural and habitation terraces or charcoal collected from off-site stream profiles (Lepofsky 1994, 1995; Lepofsky et al. 1992). All but 2 of these dates were measured using AMS (Lepofsky 1995), and these dates firmly established the relative antiquity of land use in the upper 'Opunohu Valley. Oakes' (1994) excavation of a rectangular house site provided 2 additional ${ }^{14} \mathrm{C}$ dates derived from a residential context. However, the valley still lacks a well-defined chronological sequence for house and temple construction, and interpretation of the 
available sequence is difficult because few archaeological contexts have been well dated. The present study provides a new corpus of ${ }^{14} \mathrm{C}$ dates from detailed household excavations and outlines a sequence of house construction and use in the upper eastern sector of the valley.

Initial interpretations of the 'Opunohu chronology, based on a limited number of conventionally dated archaeological contexts (Green et al. 1967) and inferences from ethnohistoric texts (Descantes 1990, 1993), suggested that the majority of surface structures dated to the early historic era. In contrast, Green's (1996) revised chronology, and another provided by Lepofsky (1994), argue for intermittent use of the valley by about AD 600 (pre-Atiro'o phase), establishment of inland surface structures by the 13th century (Atiro 'o phase), and evidence for status differentiation in domestic structures originating between the 13th-17th centuries (mid-Atiro 'o to Marama phase). From 18051815 (Pomare phase), the valley gradually emptied as its occupants converted to Christianity and relocated to coastal villages situated near newly established missions.

The precise dating and identification of contemporaneous households occupied in the last few centuries before European contact (the late prehistoric sequence) in Eastern Polynesia continues to be a problem because of imprecision in conventional ${ }^{14} \mathrm{C}$ dating and fluctuations in the calibration curve during the last $500 \mathrm{yr}$ (Weisler et al. 2006:2). As reported here, targeted AMS dating of multiple structures within Society Islands habitation complexes provides data on multiple site construction sequences and allows for assessment of site contemporaneity, which is critical for establishing the comparability of the material assemblages from excavated house sites and offering a framework for understanding changing patterns of site use over time (Tringham 1988; Weisler et al. 2006). Establishing the chronology of house construction and use is also relevant for evaluating whether site permanence and continuity was an avenue for negotiating and objectifying household rank and status in the Society Islands.

\section{SITE BACKGROUND AND CONTEXT}

The sites from which the ${ }^{14} \mathrm{C}$-dated samples derive are situated in the upper reaches of the Tupauruuru (eastern) sector of the 'Opunohu Valley. House sites ScMo-170, ScMo-171B, ScMo-171C, ScMo-120B, and ScMo-123A and temple site ScMo-171F were first mapped and described by Green in the 1960s (Green and Descantes 1989). The dated structures are situated in 3 site complexes. ScMo-170/171 is a residential complex comprised of 7 stone structures, which include house sites 170,171B, 171C; several stone faced terraces; and 171F, a simple marae enclosure. Site complex ScMo-120 has elaborate architectural features, including a round-ended house site (120B), several paved terraces, a raised stone platform, and a complex marae. The ScMo-123 complex consists of 5 distinct stone structures, including a rectangular house site (123A) with an adjacent paved area to the west, 2 large marae (123B and 123C), and a substantial earthen terrace separating the house site from the 2 marae.

Detailed excavations of the house structures were completed during 2000-2001, as part of an investigation into economic and social variability at the household scale in the Society Islands chiefdoms (Kahn 2001, 2003, 2005; Kahn and Kirch 2003, 2004). The excavated house sites include large oval-ended houses (fare pote ' $e$ ) with elaborate architectural features $(170,120 \mathrm{~B})$ and smaller, less architecturally complex rectangular houses (fare haupape) (171B, 171C, and 123A). House sites $170,171 \mathrm{~A}, 171 \mathrm{~B}$, and $171 \mathrm{C}$ were used for domestic purposes (as sleeping houses), while sites 120B and 123A were used for specialized activities and were not associated with everyday domestic use (Kahn 2005). Limited excavations at the $171 \mathrm{~F}$ marae were carried out to date the use of the marae rather than the time of its initial construction. 


\section{METHODS}

In order to assess the age and time span of occupation for the excavated houses, 11 samples of charcoal were submitted for AMS ${ }^{14} \mathrm{C}$ dating to the Beta Analytic Laboratory, Miami, USA (lab code Beta). When selecting charcoal samples for radiometric dating, every attempt was made to date charcoal from in situ fire combustion feature contexts (see Table 1). This was a viable option for dating the majority of cultural deposits associated with house occupation. When not possible, isolated charcoal fragments from undisturbed deposits (based on excavation observations) were selected. James Coil of the UC Berkeley Oceanic Archaeology Laboratory identified the charcoal in each sample in order to select wood from short-lived taxa (Table 1), thus minimizing the "old wood" problem and the impact of "inbuilt age" (Anderson 1991; Dye 2000; McFadgen 1982). In 9 cases, fragments of purau (Hibiscus tiliaceus) were selected as the most appropriate dating material. This is a soft-wood and a relatively short-lived weedy shrub that does not have a significant inbuilt age that could bias the ${ }^{14} \mathrm{C}$ determinations. Wood charcoal samples targeted for dating ScMo-123A lacked purau fragments. Samples of an unidentified dicotyledonous wood were taken from Feature 10, an in situ burn interpreted as initial site use/vegetation clearing (Beta-165116). An identified fragment of breadfruit (Artocarpus sp.) wood charcoal was submitted for dating the construction of the 123A house terrace (Beta-193935). This sample has a slightly higher potential for some inbuilt age bias, given that breadfruit is a longer lived taxa and house posts fashioned from breadfruit may have been later reused as firewood. I am confident that the ${ }^{14} \mathrm{C}$ ages obtained for the fragments of Hibiscus tiliaceus (purau) should accurately reflect the true age of site occupation and use. Both of the ScMo-123A samples had the possibility to yield results with inbuilt age biases. However, given the consistency of the calibrated age ranges from the ScMo-123A dated samples, this seems unlikely.

Laboratory methods reported by the Beta Analytic Lab were standard. The charcoal samples were pretreated and examined for rootlets, followed by a hot acid wash to remove carbonates, rinsing to neutrality, another acid wash, and another rinsing to neutrality. The OxCal program was used to calibrate conventional ${ }^{14} \mathrm{C}$ ages (atmospheric data from Stuiver et al. [1998], calibrated using OxCal v 3.9, Bronk Ramsey [2003]).

\section{RESULTS}

Results are presented in Table 2; Figure 1 is an OxCal plot of all ${ }^{14} \mathrm{C}$ sample ages shown as probability distributions. The latter includes the 2 samples dated by Oakes (1994) from her excavation of rectangular house ScMo-171A, situated below ScMo-170 in the 170/171 complex.

\section{The ScMo-170/171 Complex}

Two wood charcoal samples from oval-ended house ScMo-170 were submitted for dating. Beta153427 dates an in situ burn located at the bottom of the cultural deposit (Layer B), just above the interface with Layer C (sterile basal deposit). Dating this in situ burn provides a terminus ante quem date below the house construction. Based on careful excavation, Beta-193936 is an isolated charcoal chunk taken from deep within the construction fill for the house terrace, just above the interface with the basal deposit of Layer $\mathrm{C}$. This sample provides a date for the initial construction of the house terrace. Both ${ }^{14} \mathrm{C}$ samples are internally consistent and Beta-193936 dates the initial house construction to the mid-15th to 16th centuries. I infer that the final phase of house occupation, associated with thin Layer A deposits, a few historic artifacts, and conversion of the oval-ended house into a rectangular house, occurred during the historic period (post AD 1767). Similar evidence for historic reuse of the complex is found at rectangular house ScMo-171C and temple site ScMo-171F. 
Table 1 Taxa identified for AMS dating and implications for interpretations.

\begin{tabular}{|c|c|c|c|}
\hline $\begin{array}{l}\text { Sample } \\
\text { ScMo- } \\
\text { (Beta-) }\end{array}$ & Dated taxa for AMS & $\begin{array}{l}\text { Implications for } \\
\text { interpretations }\end{array}$ & $\begin{array}{l}\text { Other identified taxa } \\
\text { in the sample }\end{array}$ \\
\hline $\begin{array}{l}120 \mathrm{~B}-1 \\
(165117)\end{array}$ & $\begin{array}{l}\text { Purau } \\
\text { (Hibiscus tiliaceus) }\end{array}$ & $\begin{array}{l}\text { Fast-growing, short-lived } \\
\text { species: little inbuilt age. }\end{array}$ & $\begin{array}{l}\text { Purau } \\
\text { (Hibiscus tiliaceus) }\end{array}$ \\
\hline $\begin{array}{l}120 \mathrm{~B}-2 \\
(193934)\end{array}$ & $\begin{array}{l}\text { Purau } \\
\text { (Hibiscus tiliaceus) }\end{array}$ & $\begin{array}{l}\text { Fast-growing, short-lived } \\
\text { species: little inbuilt age. }\end{array}$ & $\begin{array}{l}\text { Breadfruit } \\
\text { (Artocarpus sp.) } \\
\text { Tahitian chestnut } \\
\text { (Inocarpus fagifer) } \\
\text { Purau } \\
\text { (Hibiscus tilicaceus) } \\
\text { Unidentifiable }\end{array}$ \\
\hline $\begin{array}{l}123 \mathrm{~A}-1 \\
(165116)\end{array}$ & $\begin{array}{l}\text { Unidentifiable } \\
\text { dicotyledonous wood }\end{array}$ & $\begin{array}{l}\text { Lacks taxonomic certainty: } \\
\text { may contain inbuilt age. }\end{array}$ & \\
\hline $\begin{array}{l}123 \mathrm{~A}-2 \\
(193935)\end{array}$ & Artocarpus sp. & $\begin{array}{l}\text { Low potential for inbuilt age, } \\
\text { but somewhat higher than for } \\
\text { Hibiscus tiliaceus. }\end{array}$ & $\begin{array}{l}\text { Breadfruit } \\
\text { (Artocarpus sp.) } \\
\text { Tahitian chestnut } \\
\text { (Inocarpus fagifer) }\end{array}$ \\
\hline $\begin{array}{l}170-1 \\
(153427)\end{array}$ & $\begin{array}{l}\text { Purau } \\
\text { (Hibiscus tiliaceus) }\end{array}$ & $\begin{array}{l}\text { Fast-growing, short-lived } \\
\text { species: little inbuilt age. }\end{array}$ & $\begin{array}{l}\text { Purau } \\
\text { (Hibiscus tiliaceus) } \\
\text { Unidentifiable }\end{array}$ \\
\hline $\begin{array}{l}170-2 \\
(193936)\end{array}$ & $\begin{array}{l}\text { Purau } \\
\text { (Hibiscus tiliaceus) }\end{array}$ & $\begin{array}{l}\text { Fast-growing, short-lived } \\
\text { species: little inbuilt age. }\end{array}$ & $\begin{array}{l}\text { Purau } \\
\text { (Hibiscus tiliaceus) } \\
\text { Miro? } \\
\text { (Thespesia Populnea) }\end{array}$ \\
\hline $\begin{array}{l}171 \mathrm{~B}-1 \\
(153428)\end{array}$ & $\begin{array}{l}\text { Purau } \\
\text { (Hibiscus tiliaceus) }\end{array}$ & $\begin{array}{l}\text { Fast-growing, short-lived } \\
\text { species: little inbuilt age. }\end{array}$ & $\begin{array}{l}\text { Tahitian chestnut } \\
\text { (Inocarpus fagifer) } \\
\text { Purau } \\
\text { (Hibiscus tilicaceus) } \\
\text { Unidentifiable }\end{array}$ \\
\hline $\begin{array}{l}171 \mathrm{C}-1 \\
(153429)\end{array}$ & $\begin{array}{l}\text { Purau } \\
\text { (Hibiscus tiliaceus) }\end{array}$ & $\begin{array}{l}\text { Fast-growing, short-lived } \\
\text { species: little inbuilt age. }\end{array}$ & $\begin{array}{l}\text { Purau } \\
\text { (Hibiscus tiliaceus) } \\
\text { Miro } \\
\text { (Thespesia Populnea) }\end{array}$ \\
\hline $\begin{array}{l}171 \mathrm{C}-2 \\
(153430)\end{array}$ & $\begin{array}{l}\text { Purau } \\
\text { (Hibiscus tiliaceus) }\end{array}$ & $\begin{array}{l}\text { Fast-growing, short-lived } \\
\text { species: little inbuilt age. }\end{array}$ & $\begin{array}{l}\text { Breadfruit } \\
\text { (Artocarpus sp.) } \\
\text { Tahitian chestnut } \\
\text { (Inocarpus fagifer) } \\
\text { Purau } \\
\text { (Hibiscus tilicaceus) } \\
\text { cf. Serianthes myriadena }\end{array}$ \\
\hline $\begin{array}{l}171 \mathrm{C}-3 \\
(193937)\end{array}$ & $\begin{array}{l}\text { Purau } \\
\text { (Hibiscus tiliaceus) }\end{array}$ & $\begin{array}{l}\text { Fast-growing, short-lived } \\
\text { species: little inbuilt age. }\end{array}$ & $\begin{array}{l}\text { Purau } \\
\text { (Hibiscus tilicaceus) }\end{array}$ \\
\hline $\begin{array}{l}171 \mathrm{~F}-1 \\
(193938)\end{array}$ & $\begin{array}{l}\text { Purau } \\
\text { (Hibiscus tiliaceus) }\end{array}$ & $\begin{array}{l}\text { Fast-growing, short-lived spe- } \\
\text { cies: little inbuilt age. }\end{array}$ & $\begin{array}{l}\text { Purau } \\
\text { (Hibiscus tilicaceus) }\end{array}$ \\
\hline
\end{tabular}


Table $2{ }^{14} \mathrm{C}$ age determinations by site.

\begin{tabular}{|c|c|c|c|c|c|c|}
\hline $\begin{array}{l}\text { Lab \# } \\
\text { Beta- }\end{array}$ & Site & Provenience & $\begin{array}{l}\text { Conventional } \\
{ }^{14} \mathrm{C} \text { age } \mathrm{BP}\end{array}$ & $\begin{array}{l}\delta^{13} \mathrm{C} \\
\% o\end{array}$ & $\begin{array}{l}\text { Calibrated } \\
\text { age at } 1 \sigma \\
\text { (AD) }\end{array}$ & $\begin{array}{l}\text { Calibrated } \\
\text { age at } 2 \sigma \\
\text { (AD) }\end{array}$ \\
\hline 153427 & 170 & $\begin{array}{l}\text { Unit N104 E101, } 64.5-66.5 \text { cmbd. } \\
\text { In situ charcoal lens at B/C inter- } \\
\text { face; initial site clearing. }\end{array}$ & $420 \pm 40$ & -26.7 & $\begin{array}{l}1430-1500 \\
(63.6 \%) \\
1600-1620 \\
(4.6 \%)\end{array}$ & $\begin{array}{l}1410-1530 \\
(79.7 \%) \\
1570-1630 \\
(15.7 \%)\end{array}$ \\
\hline 193936 & 170 & $\begin{array}{l}\text { Unit N101.31 E98.07 } 129 \mathrm{cmbd} \text {. } \\
\text { Isolated chunk, bottom of B fill } \\
\text { above interface with Layer C1. } \\
\text { Dates the initial house terrace } \\
\text { construction. }\end{array}$ & $370 \pm 40$ & -26.2 & $\begin{array}{l}1450-1530 \\
(42.4 \%) \\
1580-1630 \\
(25.8 \%)\end{array}$ & $\begin{array}{l}1440-1640 \\
(95.4 \%)\end{array}$ \\
\hline 153428 & $171 \mathrm{~B}$ & $\begin{array}{l}\text { Unit N97 E101. Feature 8: } \\
\text { earth oven, house exterior. }\end{array}$ & $250 \pm 40$ & -26.3 & $\begin{array}{l}1520-1560 \\
(11.4 \%) \\
1630-1680 \\
(38.5 \%) \\
1770-1800 \\
(15.6 \%) \\
1940-1950 \\
(2.7 \%)\end{array}$ & $\begin{array}{l}1510-1600 \\
(23.8 \%) \\
1610-1690 \\
(43.2 \%) \\
1730-1810 \\
(23.9 \%) \\
1930-1950 \\
(4.5 \%)\end{array}$ \\
\hline 193937 & $171 \mathrm{C}$ & $\begin{array}{l}\text { N99.86 E95.71 } 147 \mathrm{cmbd} \text {. } \\
\text { Isolated chunk, bottom of B3 } \\
\text { above interface with C1. }\end{array}$ & $130 \pm 40$ & -25.2 & $\begin{array}{l}1670-1740 \\
(21.4 \%) \\
1750-1760 \\
(2.2 \%) \\
1800-1890 \\
(33.3 \%) \\
1910-1950 \\
(11.3 \%)\end{array}$ & $\begin{array}{l}1670-1780 \\
(39.2 \%) \\
1790-1960 \\
(56.2 \%)\end{array}$ \\
\hline 153429 & $171 \mathrm{C}$ & $\begin{array}{l}\text { Unit N99 E98, Feature 9: } \\
\text { combustion feature (scoop hearth), } \\
\text { house interior. }\end{array}$ & $400 \pm 40$ & -23.9 & $\begin{array}{l}1440-1520 \\
(57.7 \%) \\
1590-1620 \\
(10.5 \%)\end{array}$ & $\begin{array}{l}1430-1530 \\
(67.3 \%) \\
1550-1640 \\
(28.1 \%)\end{array}$ \\
\hline 153430 & $171 \mathrm{C}$ & $\begin{array}{l}\text { Unit N100 E98, Feature 5: } \\
\text { hearth, house exterior. }\end{array}$ & $460 \pm 40$ & -25.9 & $\begin{array}{l}1415-1470 \\
(68.2 \%)\end{array}$ & $\begin{array}{l}1400-1510 \\
(93.8 \%) \\
1600-1620 \\
(1.6 \%)\end{array}$ \\
\hline 193938 & $171 \mathrm{~F}$ & $\begin{array}{l}\mathrm{N} 100.87 \text { E } 100.3865 \text { cmbd. } \\
\text { Isolated chunk from cultural } \\
\text { deposit B. }\end{array}$ & $150 \pm 30$ & -26.0 & $\begin{array}{l}1670-1700 \\
(11.2 \%) \\
1720-1780 \\
(29.4 \%) \\
1800-1820 \\
(6.7 \%) \\
1840-1880 \\
(7.4 \%) \\
1910-1950 \\
(13.5 \%)\end{array}$ & $\begin{array}{l}1660-1800 \\
(78.1 \%) \\
1910-1960 \\
(17.3 \%)\end{array}$ \\
\hline 165117 & $120 \mathrm{~B}$ & $\begin{array}{l}\text { Unit N97 E104, Feature 16: } \\
\text { combustion feature, house interior. }\end{array}$ & $240 \pm 40$ & -26.4 & $\begin{array}{l}1530-1550 \\
(4.4 \%) \\
1630-1680 \\
(37.6 \%) \\
1770-1810 \\
(21.2 \%) \\
1930-1950 \\
(5.0 \%)\end{array}$ & $\begin{array}{l}1520-1600 \\
(14.4 . \%) \\
1620-1690 \\
(41.6 \%) \\
1730-1810 \\
(32.5 \%) \\
1920-1950 \\
(6.9 \%)\end{array}$ \\
\hline
\end{tabular}




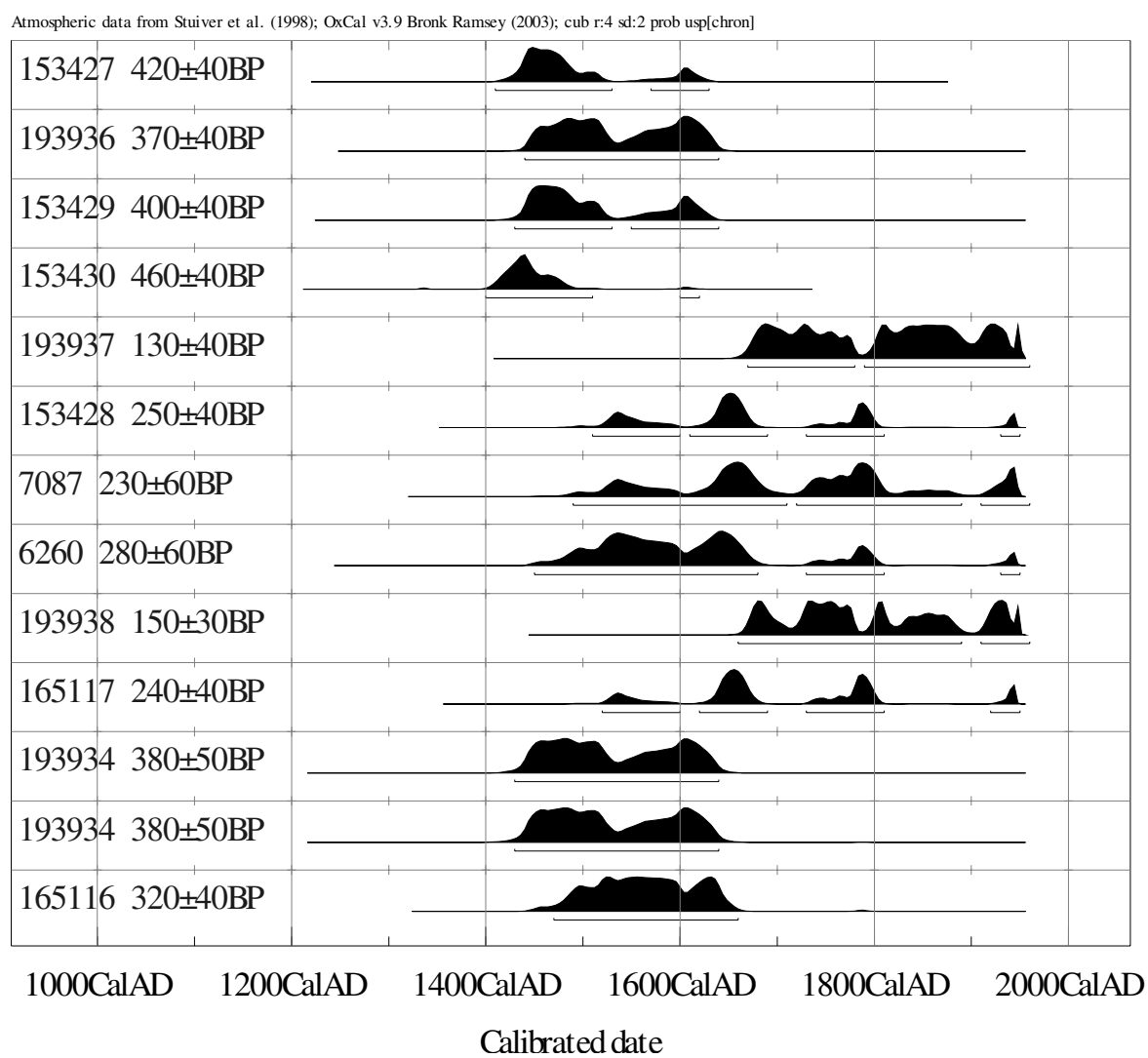

Figure 1 OxCal multiplot of calibrated ${ }^{14} \mathrm{C}$ age determinations

Three wood charcoal samples were submitted for dating rectangular house ScMo-171C. Beta153429 dates a scoop hearth situated in the house interior, associated with the main cultural deposit (Layer B). Beta-153430 was taken from a hearth located just exterior to the house and associated with the main cultural deposit (Layer B). These 2 samples are internally consistent and indicate that the main period of occupation at ScMo-171C was sometime between the mid-15th to mid-16th centuries. This is similar to findings for ScMo-170. Based on careful excavation, Beta-193937 represents an isolated charcoal chunk situated at the bottom of the main cultural deposit (Layer B), just above the interface with the basalt deposit (Layer C). This sample yielded a surprisingly young and inverted date that diverges from the other dated samples from firm contexts (Beta-153429 and Beta153430). Given the anomalous result, Beta-153429 is interpreted as dating an intrusive feature associated with the Layer A deposit, perhaps a pit or posthole feature that was not recognized during the excavations.

A single wood charcoal sample from the 171B rectangular house was submitted for dating. The sample was recovered from a large earth oven $(и т u)$ associated with the cultural deposit (Layer B) and located outside the curbstone outline of the house structure.

As frequently occurs with ${ }^{14} \mathrm{C}$ samples dating to the last half-millennium, there are multiple "intercepts" when one plots the ${ }^{14} \mathrm{C}$ ages against a calibration curve, resulting in the multiple calibrated ages. In some cases, these include calibration ranges falling into the post-contact period (as for sites 
$171 \mathrm{~A}, 171 \mathrm{~B}, 171 \mathrm{C}, 171 \mathrm{~F})$. The calibrated results indicate that the 171B rectangular house was most likely occupied sometime in the 17th century, during the late Atiro'o to early Marama phases. This is consistent with Oakes' (1994) ${ }^{14} \mathrm{C}$ samples from the 171 A rectangular house, where the construction and use of the house and adjacent terrace date to the mid-17th to mid-18th centuries.

Finally, a single wood charcoal sample from marae $171 \mathrm{~F}$ was submitted for dating. Because of time constraints, excavations at $171 \mathrm{~F}$ focused on the cultural deposits (Layer B) rather than the time-consuming excavation of the underlying construction fill. Because of this, Beta-193938, a wood charcoal sample taken from the cultural deposit, dates the use of the marae rather than its initial construction. This sample yielded an age range indicative of temple use during the mid-17th to 19th centuries, which correlates with the historic reuse of the complex demonstrated at ScMo-170 and ScMo-171C. This date, like Beta-193937, does not overlap with the other dated samples for the complex at $2 \sigma$ and correlates to the later phase of complex use during the Marama to Pomare phases.

\section{The ScMo-120 Complex}

Two charcoal samples were dated from ScMo-120 contexts. Beta-193934, an isolated charcoal chunk taken from the bottom of the Layer B construction fill, just above the interface with sterile Layer $\mathrm{C}$ soil, dates the initial use of the site prior to the construction of the ScMo-10B house and house terrace. It yielded an age range of cal AD 1470-1660 at $2 \sigma$, while the 1- $\sigma$ calibrated age ranges suggest that initial use of the site was during the mid-15th to 16th centuries. Beta-165117 was taken from an in situ fire combustion feature in the house interior, cut from the bottom of the Layer B cultural deposit into the underlying construction fill. The sample has multiple calibrated ages, including ranges falling into the post-contact period. The most likely date for the cultural deposit (Layer B) associated with the construction and occupation of the ScMo-120B house is in the mid-17th century.

Overall, the samples indicate construction and use of the site during the mid- to late Atiro 'o phase. The 2 samples barely overlap at $2 \sigma$, suggestive of 2 phases of site occupation. Initial use of the area, prior to the construction of the house, was established sometime after the mid-15th century. The activities pre-dating the house construction likely involved site clearance and perhaps other activities. The house terrace and house proper were constructed sometime during the 17th century.

\section{The ScMo-123 Complex}

Excavations at the ScMo-123A rectangular house did not recover in situ remains of cooking hearths or combustion features directly associated with the house that were suitable for dating. Dating samples were taken from other appropriate contexts in areas exterior to the house to date site construction and use. The 2 dated wood charcoal samples yielded highly consistent calibrated age ranges. Beta-193935 is an isolated charcoal chunk taken from the top of the Layer B fill construction deposit that the ScMo-123A house was built upon. Given its proximity to the rectangular curbstone outline, the sample likely dates the initial construction and use of the house terrace and house proper. Beta165116 was taken from an in situ location at the interface between the Layer B fill construction deposit and the underlying Layer $\mathrm{C}$ (basal deposit) on the terrace between the 123A rectangular house and the 123B marae. This in situ burning relates to activities pre-dating the house and thus provides a terminus ante quem date below the house construction. The calibrated ${ }^{14} \mathrm{C}$ age determinations are internally consistent, providing age ranges between the mid-15th to mid-17th centuries. This suggests that initial construction of the house terrace and of the rectangular house date to the late Atiro`o phase. 


\section{DISCUSSION: CONSTRUCTION SEQUENCES, SITE CONTEMPORANEITY, AND REVISIONS TO THE LOCAL 'OPUNOHU VALLEY CHRONOLOGY}

Taken as a group, the central tendency of this new suite of ${ }^{14} \mathrm{C}$ dates from the 'Opunohu Valley documents site construction and occupation in the late prehistoric period, rather than the historic period. Nine of the $11{ }^{14} \mathrm{C}$ dates fall within the late Atiro 'o to Marama phases of the 'Opunohu sequence as defined by Green (1996), supporting an interpretation of maximal population density in the centuries immediately prior to European contact (AD 1767). These 9 samples yielded internally consistent results, indicating that the structures in complexes ScMo-120, ScMo-123, and ScMo-170/171 were contemporaneously occupied in the late prehistoric period between the 15 th and mid-17th centuries. Two dates, one from ScMo-171C (Beta-193937) and another from ScMo-171F (Beta193938), do not overlap with the other ${ }^{14} \mathrm{C}$ dates at $2 \sigma$. These samples fall within the MaramaPomare phases as defined by Green and date the most recent, historic reoccupation and use of the ScMo-170/171 complex. The dates suggest the possibility of 3 phases of occupation at the ScMo170/171 complex, with an initial phase dating to the 15th century (at structures 170 and 171C), followed by a second phase in the 16th and 17th centuries (with the construction of structures 171A and 171B). Sites 123A and 120B also date to this second phase. The final phase of site occupation and reuse at the ScMo-170/171 complex, at structures $171 \mathrm{C}$ and $171 \mathrm{~F}$, dates to the mid-17th to 18 th centuries, demonstrating reuse of the habitation complex in the historic period.

Overall, the suite of ${ }^{14} \mathrm{C}$ dates from the excavated complexes establishes their contemporaneity, as well as their use over time (particularly for the ScMo-170/171 complex). Establishing site contemporaneity allows for inter- and intra-site comparisons between these neighboring complexes to be made concerning the types and intensity of activities carried out through time, which is critical to establishing site function (see Kahn 2005). The data are equally significant to interpretations of site continuity and growth relevant to the development and maintenance of residential groups and their house clusters through time (Kahn, forthcoming). Within residential complex ScMo-170/171, my data support the construction of the initial founding house, the ScMo-170 oval-ended house, at the same time as the ScMo-171C rectangular house. Several generations after this initial phase of house building and site occupation, the residential group expanded with the construction of structures ScMo-171A and ScMo-171B.

The dates also have important implications for the local 'Opunohu Valley settlement chronology. The sequence of site construction, use, and possible reuse in the upper Tupauruuru sector of the valley has been a topic of ongoing debate (Descantes 1990, 1993; Green 1996; Green et al. 1967; Lepofsky 1994). Taxonomic identifications of charcoal samples from these 11 upper Tupauruuru house and temple contexts (Table 1) demonstrate that by the time of site construction and occupation, the upper valley had few native species and was dominated by assorted cultigens and successional forest species like Hibiscus tilicaceus, which are dominate in disturbed environments. This is consistent with Lepofsky's identification of charcoal from upper Tupauruuru agricultural contexts, where early successional vegetation was found in the earliest dated layers, indicating the primary forest had already been transformed by the 13th century (Lepofsky 1994:288-289; Lepofsky et al. 1996: 269). My data, from 15th century contexts and later, suggests a human-altered tree-cropping and/or swidden-dominated landscape, with breadfruit and Tahitian chestnut well represented (Table 1), broadly supporting Lepofsky's proposition (1994:290; Lepofsky et al. 1996:269) that the valley had already been used, perhaps for some time, for arboriculture and swidden agriculture.

The new AMS dates data clearly support dense residential settlement of the upper Tupauruuru portion of the 'Opunohu Valley dating to the late prehistoric period. This reinforces Green's (1996) 
reinterpretation of the local 'Opunohu chronology and that provided by Lepofsky (1994). However, it contradicts the initial interpretation of the 'Opunohu chronology (Green et al. 1967), as well as that offered by Descantes $(1990,1993)$, which suggested that the majority of surface structures in the valley dated to the early historic era. The ScMo-170/171, ScMo-120, and ScMo-123 dates place the construction of these residential sites during the later part of the Atiro'o (AD 1000-1650) to Marama (AD 1650-1788) cultural phases as defined by Green (1996). The ${ }^{14} \mathrm{C}$ dates support Green's assertion (1996:218) that during the later part of the Atiro 'o phase, house sites were differentiated according to social status and also confirm the presence of "a well-established community of status individuals" in this sector of the valley. I can now refine this assertion, as house sites were clearly differentiated according to rank and status by the mid-15th century.

Continued use of the 170/171 complex is established by a final phase of site use dated to the late Marama to Pomare periods. Material manifestations of this later historic use of the complex are diffuse but present at structures 170, 171 A, 171C, and 171F. For example, evidence for a brief period of reoccupation in the post-contact period at $171 \mathrm{C}$ includes a small number of historic artifacts, notably pieces of bottle glass, window glass, and metal. Small stake holes and larger posthole features were also recovered in the top $5 \mathrm{~cm}$ of the site deposits, stratigraphically above the main cultural occupation level. This represents a brief period of site reoccupation or reuse, likely sometime after European contact in AD 1767. House site ScMo-170 also has some evidence for a period of reoccupation, when the curbstone outline of the oval-ended house was robbed to construct a stratigraphically later rectangular house within the outline of the former oval-ended house. Oakes' (1994: 89, 94-95) excavations at ScMo-171A recovered a small piece of copper and a fragment of green glass in the top surficial deposits at the site. Given the recovery of a similar constellation of historic period artifacts at ScMo-171C, the data suggest brief reuse of this structure during the historic period. The dated charcoal sample from $171 \mathrm{~F}$ similarly suggests continued use of the marae into the historic period.

While researchers have argued that the upper slopes of the Tupauruuru section served as a refuge in the Pomare period for traditionalists avoiding missionary activities on the coast (Descantes 1993; Eddowes 1991; Green 1996), archaeological survey and excavation has not yet yielded significant evidence for historic reoccupation of many sites in the valley. For example, while ScMo-171C has the most evidence for historic reuse, the material manifestations of this later site use are minimal and I have argued they differ greatly from those described by Eddowes (2001) for a Papeno'o Valley (Tahiti) rectangular house site (TAH-033-105), interpreted as a residence for traditionalist refugees in the historic period (Kahn 2003). The reuse of 'Opunohu Valley sites 170, 171C, and 171A does not appear to represent a substantial or permanent reoccupation of these sites in the post-contact period, but does suggest that these sites were revisited and reused for brief periods following European contact. A similar argument can be made for the ongoing use of the $171 \mathrm{~F}$ marae. I believe the historic reuse of the 170/171C complex suggests attempts to maintain a relationship with ancestral family lands, house sites, and family temples during the chaotic post-contact era (Kahn 2003, 2005).

\section{CONCLUSIONS}

This chronometric sequence provides one of the first systematic investigations of residential site chronology in the Society Islands. Targeted AMS dating of charcoal samples identified to shortlived taxa has refined site construction sequences, identified multiple episodes of building in a house cluster, established site contemporaneity, and demonstrated growth in a house cluster through time. 
In the 'Opunohu Valley, well-established residences and specialized houses for ritual activities, both associated with the ruling social and ritual elites, are evident during the 15th century. The new AMS dates clearly support dense residential settlement of this windward interior valley in the late prehistoric period, with maximal population density suggested for the centuries immediately prior to European contact. Additional dating of interior windward contexts in the Society Islands are now critical if we are to construct a regional cultural sequence and outline the expansion of settlement from coastal areas into valley interiors. Current 'Opunohu Valley data indicates that the majority of surface structures were built in the late prehistoric period. This contradicts earlier interpretations based on a limited number of conventionally dated archaeological contexts and inferences from ethnohistoric texts, which suggested that the majority of surface remains were constructed and used in the early historic era (post AD 1767). Artifactual, stratigraphic, and chronometric data from newly excavated ritual and domestic contexts indicates that sites were visited and reused in the historic period, yet the ephemeral nature of the deposits does not support the interpretation that the upper valley served frequently as a refuge in the historic era.

Dating multiple structures within house cluster ScMo-170/171 has effectively demonstrated 3 distinct phases for site construction and use, providing data on the developmental cycle of this residential group and growth in the house cluster through time. Refined chronological data, particularly in multi-structure house complexes and between different site complexes within prehistoric neighborhoods, is one of many attributes that can be used to interpret differential household rank, social status, and the relationship between principal and affiliated households. Further targeted dating of multiple structures within late prehistoric Polynesian house clusters are needed if long-standing models concerning the emergence and development of status inequality at the household level are to be tested.

\section{ACKNOWLEDGMENTS}

I thank Patrick Kirch and Rosemary Joyce for comments on an earlier draft of this paper. Funds for the ${ }^{14} \mathrm{C}$ dates were provided by a private donation by Roger Green and grants awarded by the Lowie Olsen Fund (Department of Anthropology, University of California, Berkeley) and the Stahl Fund (Archaeological Research Facility, University of California, Berkeley).

\section{REFERENCES}

Anderson A. 1991. The chronology of colonization in New Zealand. Antiquity 65:767-95.

Anderson A, Leach H, Smith I, Walter R. 1994. Reconsideration of the Marquesan sequence in East Polynesian prehistory, with particular reference to Hane (MUH1). Archaeology in Oceania 29:29-52.

Bronk Ramsey C. 2003. OxCal program v3.9 [software and online manual]. URL: http://www.rlaha.ox.ac.uk/ oxcal/oxcal.htm.

Davidson JM. 1967. Excavations of two round-ended house sites in the eastern portion of the 'Opunohu Valley. In: Green RC, Green K, Rappaport RA, Rappaport A, Davidson J, editors. Archaeology on the Island of Mo'orea, French Polynesia. Anthropological Papers of the American Museum of Natural History 51(2): $118-40$.

Descantes C. 1990. Symbolic stone structures: protohistoric and early historic spatial patterns of the 'Opunohu Valley, Mo'orea, French Polynesia [MA thesis]. Auckland: University of Auckland.

Descantes C. 1993. Marae of the 'Opunohu Valley, Mo'orea, Society Islands, French Polynesia. Journal of the Polynesian Society 102(2):187-216.

Dye TS. 2000. Effects of ${ }^{14} \mathrm{C}$ sample selection in archaeology: an example from Hawai' $i$. Radiocarbon 42(2): 203-17.

Eddowes M. 1991. Ethnohistorical perspectives on the marae of the Society Islands: the sociology of use [MA thesis]. Auckland: University of Auckland.

Eddowes M. 2001. Transformation des pratiques religieuses de la fin du culte Hui Arii: les cultes Tutae Auri et Mamaia et leur présence dans la Haute Vallée de la Papenoo de 1815 a 1840. Bulletin de la Société des Etudes Océaniennes 289-291:37-75.

Green RC. 1996. Settlement patterns and complex society in the Windward Society Islands: retrospective commentary from the 'Opunohu Valley, Mo'orea. In: Julien M, Orliac M, Orliac C, editors. Mémoire de 
Pierre, Mémoire d'Homme: Tradition et Archéologie en Océanie. Paris: Publications de la Sorbonne. p 209-28. In French.

Green RC, Green K, Rappaport RA, Rappaport A, Davidson J. 1967. Archaeology on the Island of Mo'orea, French Polynesia. Anthropological Papers of the American Museum of Natural History 51(2): $111-230$.

Kahn JG. 2001. Rapport des activités de recherche archéologique dans la Vallée d'Opunohu, Mo 'orea, du 7 juillet au 30 aout 2001 [report prepared for the Ministre de la Culture]. Gouvernement du Territoire, Polynésie Française.

Kahn JG. 2003. Maohi social organization at the microscale: household archaeology in the 'Opunohu Valley, Mo'orea, Society Islands (French Polynesia). In: Sand C, editor. Pacific Archaeology: Assessments and Prospects. Nouméa: Le Cahiers de l'Archéologie en Nouvelle-Calédonie 15. p 353-67.

Kahn JG. 2005. Household and community organization in the late prehistoric Society Islands (French Polynesia) [PhD dissertation]. Berkeley: University of California.

Kahn JG. Forthcoming. Power and precedence in Ancient House societies: a case study from the Society Island chiefdoms (French Polynesia). In: Beck R, editor. The Durable House: Architecture, Ancestors, and Origins. Carbondale: Southern Illinois University, Center for Archaeological Investigation.

Kahn JG, Kirch PV. 2003. The ancient 'House Society' of the 'Opunohu Valley, Mo'orea: overview of an archaeological project, 2000-2002. In: Marchesi H, editor. Bilan de la recherche archéologique en Polynésie française 2001-2002. Dossier d'Archeologie polynésienne 2. Punaauia: Service de la Culture et du Patrimoine. p 21-36.

Kahn JG, Kirch PV. 2004. Ethnographie préhistorique d'une "société à maisons" dans la vallée de "Opunohu (Mo “orea, îles de la Société). Journal de la Société des Océanistes 119:229-56.

Kirch PV. 1986. Rethinking East Polynesian prehistory. Journal of the Polynesian Society 95:9-40.

Kirch PV. 2000. On the Road of the Winds: An Archaeo- logical History of the Pacific Islands Before European Contact. Berkeley: University of California Press. $424 \mathrm{p}$.

Lepofsky D. 1994. Prehistoric agricultural intensification in Society Islands, French Polynesia [PhD dissertation]. Berkeley: University of California.

Lepofsky D. 1995. A radiocarbon chronology for prehistoric agriculture in the Society Islands, French Polynesia. Radiocarbon 37(30):917-30.

Lepofsky D, Harries H, Kellum M. 1992. Early coconuts on Mo 'orea Island, French Polynesia. The Journal of the Polynesian Society 101:299-308.

Lepofsky D, Kirch PV, Lertzman KP. 1996. Stratigraphic and paleobotanical evidence for prehistoric-induced environmental disturbance on Mo'orea, French Polynesia. Pacific Science 50:253-73.

McFadgen BJ. 1982. Dating New Zealand archaeology by radiocarbon. New Zealand Journal of Science 25: 379-92.

Oakes NR. 1994. The late prehistoric Maohi fare haupape: an examination of household organization in Mo'orea, French Polynesia [MA thesis]. Vancouver: Simon Fraser University.

Rolett BV. 1998. Hanamiai: Prehistoric Colonization and Cultural Change in the Marquesas Islands (East Polynesia). Yale University Publications in Anthropology \#81. New Haven: Department of Anthropology and the Peabody Museum.

Spriggs MJ, Anderson A. 1993. Late colonization of East Polynesia. Antiquity 67:200-17.

Stuiver M, Reimer PJ, Bard E, Beck JW, Burr GS, Hughen KA, Kromer B, McCormac FG, van der Plicht, J, Spurk M. 1998. IntCal98 radiocarbon age calibration, 24,000-0 cal BP. Radiocarbon 40(3):104183.

Tringham R. 1988. Households, Housefulls, and Archaeological House Remains: Social Archaeology at a Microscale [unpublished plenary address]. Alberta: 21st Annual Chacmool Conference, University of Calgary. Weisler MI, Collerson KD, Feng YX, Zhao JX, Yu KF 2006. Thorium-230 coral chronology of a late Prehistoric Hawaiian chiefdom. Journal of Archaeological Science 33(2):273-82. 